J OURNAL OF French and Francophone Philosophy
RE V UE DE LA

philosophie française et de langue française

\title{
The Ethics of Uncovering the Something Else in Histoire(s) du cinéma
}

Jiewon Baek

Journal of French and Francophone Philosophy - Revue de la philosophie française et de langue française, Vol XXII, No 1 (2014) pp 40-60.

\author{
Vol XXII, No 1 (2014) \\ ISSN 1936-6280 (print) \\ ISSN 2155-1162 (online) \\ DOI $10.5195 /$ jffp. 2014.642 \\ www.jffp.org
}

\section{(c) EY-NC-ND}

This work is licensed under a Creative Commons Attribution-Noncommercial-No Derivative Works 3.0 United States License.

\section{ULIS D-Sunt}

This journal is operated by the University Library System of the University of Pittsburgh as part of its D-Scribe Digital Publishing Program, and is co-sponsored by the University of Pittsburgh Press 


\title{
The Ethics of Uncovering the Something Else
} in Histoire(s) du cinéma

\author{
Jiewon Baek \\ University of Minnesota
}

Après l'écriture du texte tout venait trop tard, tout, parce que l'événement avait déjà eu lieu, justement, l'écriture. Parce que l'écriture, qu'elle soit écrite ou lue, c'est ici identique, c'est pareillement le partage de l'histoire générale. Cette histoire ici, qui est à tous, j'avais le droit, moi, d'en avoir ma part puisque c'est comme ça que moi, je la partage avec les autres, en écrivant. Mais peut-être n'avais-je pas le droit ici - ici, je crois au mal, au diable, à la morale - une fois l'écriture passée, une fois pénétrée et refermée cette nuit commune du gouffre, de faire comme s'il était possible d'y revenir voir une deuxième fois.

- Marguerite Duras, Le navire night

Marguerite Duras prefaces the second edition of Le navire night, from which an excerpt is cited above, by explaining that after writing the story of a man named J.M., everything came too late, including the realization of the film version of Le navire night. Once the event has been written and the common night of history been closed up, did she have the right to flash a light into the darkness to go back and see? The only seeing through cinema that was possible, she continues, was to film the failure, the disaster of the film. But how does one film the failure of realizing a film adaptation of a written text, which itself was transcribed from an oral re-telling of a story, which itself was adapted from memory? The event already took place - writing, "this history here" -, leaving cinema to film what never took place, namely, the film itself. As Jean-Luc Godard confirms in a chapter titled Seul le cinéma in Histoire(s) du cinéma, not only in the form of his project as a whole but also more explicitly in one shot that positions two close-up photographs of his face with the sound of Paul Hindemith's "Funeral Music" and this text: "Faire une description précise de ce qui n'a jamais eu lieu est le travail de 
l'historien." Describing the rise of the film Le navire night from its disastrous death, Duras writes: “On a mis la caméra à l'envers et on a filmé ce qui entrait dedans, de la nuit, de l'air, des projecteurs, des routes, des visages aussi." 1 The camera turned upside-down, or in the other sense, inside-out, Duras films the entrance of the exterior, a sort of a Levinasian visage. The question no longer is one of having the right but of the duty to re-write history, as is insinuated by the reference to "The Critic as Artist" written across one of the photographs mentioned above, which is again a gesture of Godard's positioning himself as the critic whose role Oscar Wilde defined: "The one duty we owe to history is to rewrite it." 2

The interplay between the event of writing and of filming in relation to history, well evident in Duras's project Le navire night, is constantly echoed in the ubiquitous presence of books in Godard's films. The very opening of Histoire(s) du cinéma embeds a literary citation, "Hoc opus, hic labor est," the Sibyl's warning to Aeneas's descent to and return from the underworld. Placed as an entry to Histoire(s) du cinéma, the quote highlights the equivocal significations of the "work" of revisiting the abyss and retracing its path out from death. How does this work - the cinematic opus and/or the filmmaker's labor - fulfill the task of un-working the histoire(s) of cinema that take part in the general shared history, "cette histoire ici"? Tellingly entitled Toutes les histoires, the first chapter of Histoire(s) du cinéma generates confounding contrasts with an image of Godard in his library that rapidly alternates with film stills, photographs, and close-ups of paintings, most often accompanied by the sound of a typewriter. This work of re-writing what never took place amidst all the histories interrupts and is interrupted by the work of other arts, which share their part in the problem of what the voice-over continues to repeat, the "histoire(s) du cinéma." What happens when this work is interrupted by the voice-over's serial evocation of Soljenitsyne's L'Archipel du Goulag, Baudelaire's Mon cour mis à nu, Stevenson's L'île au trésor, Jules Verne's Les cinq cents millions de la Bégum, and Heidegger's Chemins qui ne mènent nulle part? What happens when the steady sound of the typewriter is interrupted when Godard takes Kœslter's Le zéro et l'infini off the bookshelf?

The History that interests Godard's thesis - that cinema betrayed its potential and its duty to testify to what is now a common abyssal night of history - is restricted to the Second World War relative to France and Germany. Rather than to view Histoire(s) du cinéma as tendentious and limited, the more productive task lies in recognizing this restricted History as the object of the film and seeking how the film engages in a critical work with its object. For reasons not limited to the presence of philosophical books nor to philosophy's own complex relationship with literature and with cinema, this interconnected event of writing and cinema presents a philosophical issue. ${ }^{3}$ I will examine Histoire(s) du cinéma as a work of philosophy in the strict sense that Emmanuel Levinas defines philosophy, as 
ethical critique. My interest is to view the film's intertextual work as an ethical event, which critically partakes in the history of cinema while undoing and uncovering the restricted History it presents. Behind this engagement with Godard and Levinas together is a two-sided aim. First I will suggest conceptual terms borrowed from Levinas's ethics as helpful for examining the montage of composite images in Histoire(s) du cinéma as not only a medium for reflection on the otherness of history, but also as a critical work that searches an alternative to the dialectic hold of ontological representation versus the "unrepresentable" of History. Secondly, I will give a critical reading of the ambiguity in Levinas's treatment of cinema and suggest by way of Godard's montage that despite Levinas's resistance, there is a possibility to think cinema as a lieu of ethics.

\section{An Ethical Language of Reduction}

To understand the film's language as an ethical event means to view the film as a cinematic engagement in the ethics of the Saying and the Said. ${ }^{4}$ Ethics, as Levinas defines it to be, is the condition of the Saying, or the "proximity of one to the other, the commitment of an approach, the one for the other, the very signifyingness of signification." 5 The Saying is a "pre-original" proximity towards alterity that is non-coincidental to the ontological language of signification. ${ }^{6}$ The signification of the Said designates, captures, immobilizes, and fixes the Saying. The task of philosophy, as Levinas specifies, is to performatively disrupt the Said and to reduce its violence against the Saying by uncovering "the otherwise than being from the said." 7

Unlike the function of philosophy, Levinas subordinates the ontological fascination and fixation with art as a mere resounding of the Said, or a "pure theme" that is immobilized in "the very impossibility of anything else, of any evolution that would not be a revolving upon oneself." 8 Despite his critical judgment in the essay "Reality and Its Shadow" against the revelatory function of art, not only did Levinas write commentaries on specific literary texts of authors such as Proust, Celan, Blanchot, and Leiris, but he also continually referenced works of literature throughout his philosophical texts, albeit sometimes by way of ellipses. ${ }^{9}$ Don Juan, SaintExupéry's Vol de Nuit, and Dostoïevski, for instance, appear in Entre Nous as occasions to illustrate the concept of the visage. In Time and the Other, besides citing Gœthe, Dante, and Léon Bloy to describe the female as a mysterious figure, Levinas resorts to thematic readings of literary texts in order to demonstrate philosophical concepts. In the same book, the philosopher confesses before briefly analyzing the ending of Macbeth: "it sometimes seems to me that the whole of philosophy is only a meditation of Shakespeare."10

As Robert Eaglestone speculates, "[i]t is possible that these texts and their use stand exactly on the fault line in Levinas's thought about language, 
representation and art. On the one hand, Levinas appeals to these works; on the other, he removes their status as anything more than beguiling 'rhythm'."11 Given this seemingly contradictory position, Eaglestone considers Levinas's re-articulations in the later Otherwise Than Being, or, Beyond Essence and advances the notion of an ethics of literary critique. ${ }^{12}$ What Levinas reformulates in this later work, as distinguished from the earlier Totality and Infinity, is a system of language in which the self, no longer an egoist moi jouissant, is always and already bound up within the proximity of the Saying. Jill Robbins has presented a study that argues for the possibility of thinking literature together with ethics. ${ }^{13}$ While in "Reality and its Shadow" and Totality and Infinity Levinas excludes poetry from ethical discourse (and even goes as far as misinterpreting and re-phrasing citations of Rimbaud and Baudelaire to do so, as Robbins remarks), essays on other authors such as Agnon, Celan, Proust, or Blanchot, gathered in Proper Names, constitute what Robbins distinguishes as "exceptions" in Levinas's negative judgment. I would add, however, that even in Totality and Infinity, Levinas's precarious and ambiguous use of literature stands at the crux of his formulation of language as a place of critique and of ethical encounter.

An instance of allusion to Shakespeare and Goethe in Totality and Infinity provides a salient example. In a subsection on the association between truth and justice, the freedom of the Same to judge the Other is contrasted to the calling-into-question of representation and knowledge, that is, critique. The Self's freedom, according to Levinas, is possible only for a solitary being in a silent world, uninterrupted by the otherwise than Being. It is this world lacking in speech, a world of anarchy, a bewitched state of non-distinction between my perspective of the world and objective truth, that Levinas makes analogous to "the situation created by those derisive beings communicating across a labyrinth of innuendos which Shakespeare and Goethe have appear in their scenes of sorcerers where speech is antilanguage." 14 The laughingly mocking beings speak an antilanguage or an "inverse of language," making impossible the opening up of communication. Only the presence of the Other can interrupt this bewitched world without speech: "Speech consists in the Other coming to the assistance of the sign given forth, attending his own manifestation in signs, redressing the equivocal by this attendance." 15 The signs emitted by the Other unsettle the freedom of the solitary being. Language as the manifestation of the Other breaks the silence and opens up the possibility of critique.

The brief as well as vague reference to the scenes from Shakespeare and Goethe must not be dismissed as a brief and vague example supplementary to the description of a philosophical concept. That Levinas appeals to literature in order to argue that language is necessary for ethics establishes a link between literature and the possibility of speech. Given that unlike the 
altered paradigm articulated in Otherwise Than Being subjectivity in Totality and Infinity remains an egoistic, free self on the basis of which the Other interrogates, the issue at hand in this latter work is how the possibility of questioning and critiquing, thus the possibility for encountering the Other's face, becomes speech. In "Reality and Its Shadow," the critic is defined as "the one who still has something to say when everything has been said, that can say about the work something else than that work." 16 Ethical critique, then, maintains this opening of speech that responds to the ethical task Levinas evokes, which is to uncover the Saying or to "extract the otherwise than being from the said." 17 The work of literary critique happens in the potential to call the silent world into question and to uncover what has been signified. Rather than as an exploitation of literature for the benefit of philosophical exposition, it would be more apt to read Levinas's treatment of literary works as allusions to literature as a lieu for sustaining the possibility to be interrupted and to be inquired, thus refusing the closure of silence. This engagement with literature in philosophical books presents literary art as ethical critique, which is a precarious operation in that literature is not merely a resounding of the Said that is fixed in the work, but rather a complex relation of simultaneous dependency and subversion between the Saying and the Said. The critical language of literature thus interrupts the silent, egoistic realm of the Same and maintains the possibility of still having something to say when everything has been said.

This paper's treatment of cinematic montage as a form of ethical critique is based on the hypothesis that if the abundance of literature in Levinas's philosophical books hints at the Saying of literature as a lieu of ethics, the abundance of literature in films and the abundance of films in philosophical discourse might give way to the Saying of film as ethical language. Given the tension between the Saying and the Said, in conjunction with the apparent ethical tension between the cinematic regime of images and cinema as a kind of philosophy, it seems necessary to question how cinema's language might be able to push at the limits of shadowy images under the disapproval of Levinas. The ethical turn in the 1990s in literary studies has extended to more recent studies in cinema that propose to think films' language as a kind of ethico-philosophical discourse. The attempt to examine cinema as a work of ethics, specifically in terms of Levinas's philosophy, has taken two disparate directions. On the one hand, studies that merge Levinasian ethics and cinema have considered how certain films serve as a sight for thematic readings that further philosophical reflections. ${ }^{18}$ On the other hand, and quite contrary to the former approach, scholars have attempted to think film as philosophy, and have argued that film has a performatory role. John Drabinski, in particular, has executed readings of several of Godard's films from the 1960s and 1970s by interjecting Godard's philosophical reflections between those of Levinas and Derrida, and his readings treat these films as primary philosophical texts that explore the ethical problem of alterity. ${ }^{19}$ 
By extending Drabinski's engagement with the language of Godard's films as an alternative mode of philosophical discourse that thinks alterity and also thinks about thinking alterity, I will more specifically develop the function of the composite image as an ethical mode of interruption. Drabinski's analyses suggest that the single-shot montage in Histoire(s) $d u$ cinéma serves as a "rendering of the unrepresentable immemorial." 20 Alternatively but not contrarily to Drabinski's approach, I view Godard's montage as a critical event that reduces the representation of the Said and uncovers the proximity of the Saying. In this way, we will be able to view Godard's project as more than dealing with the tension of the "unrepresentable" in the form of images.

\section{Uncovering the Saying: The "Something That Might Have Changed"}

Histoire(s) du cinéma works through a central paradox. In describing the film as a thwarted fable that redeems the representative mode of images from their presence as pure icons, Jacques Rancière assesses this paradox negatively. Through his use of images, Godard at once affirms the innocent power of cinema's icons of pure presence and condemns its betrayal against history and against itself. ${ }^{21} \mathrm{He}$ at once affirms the autonomy of the image and submits the image to the mimetic mode. Rather than discrediting itself as a project, however, as it does in Rancière's conclusion, the film works through the paradox in a productive manner.

According to Rancière, the virtue of cinema's images for Godard lies in their ability to function as the true mark of the world, the imprint of reality as the face on Veronica's veil. ${ }^{22}$ Cinema betrayed this essence when it turned to Hollywood's fictions. Paradoxically, the history that Godard presents with this overarching thesis would not be possible without Hollywood's images. His demonstration of the pure, unadulterated power of images would not be possible without Hollywood's icons, which constitute a bulk of his corpus of materials. But given this paradox, or rather through this paradox, something else happens. The veils imprinted with the events of history are made to clash with the veils imprinted with the images of Hollywood. And in this clashing, which is not identical to the pasting (collage) that Rancière sees in the images, emerges the ethical event of uncovering the Saying. Rather than maintaining a dialectical tension on the basis of what is imprinted on the veil, the interaction of materials in Histoire(s) du cinéma effects a critique through what occurs at the overlapping of these veils as such, as veils with an imprint of the Said that covers up the Saying.

This critical endeavor is compelled by the responsibility imposed upon by an unsignifiable Other that causes a breakup of what is Said to be the 
essence of cinema. This proximity or responsibility is the Saying that confronts Godard's project on two interrelated levels: on the one level, the Saying is the "one for the other" or "exposedness" of cinema towards a global history to which it must attest; on the other level, the Saying is the responsibility of cinema towards its own history in proximity with the histories of other media. Throughout the lectures published in The Introduction to a True History of Cinema and Television, Godard addresses the problem of an invisible "something else" that ruptures the existing history of cinema. The idea of Infinity interrupts cinema's history as totalizing or essential. Godard illustrates the regime of "normalized" representation with the dominant reception of talking film versus silent film. ${ }^{23}$ The history of cinema that has come to be considered "normal" is disrupted by something else that demands cinema to respond, yet films cannot depict that Other. Godard's work confronts a breaking up of its inwardness by the Saying, the proximity towards "something that might have changed." 24 This history of "something that might have changed," Godard states, exceeds what is shown in films that have been made and remains invisible. ${ }^{25}$ Cinema has a history, a pre-original proximity, which never took place. The "very history of cinema," writes Godard, "which should be the easiest thing in the world to do and see, is absolutely impossible to see." 26 Histoire(s) du cinéma ventures to uncover the invisible "something else" by a disruption of essentializing regimes, whether that of pure autonomous images or that of narrative cinema.

In contesting Rancière's understanding of a sequence on Hitchcock in episode 4A, Le contrôle de l'univers, Daniel Morgan suggests that we should not take the claims of Godard's voice-over plainly and conclude that the project adheres to the "primacy of images over plot." 27 Underscoring the power of cinematic detail, according to Morgan, does not directly result in decontextualization. While Rancière and Richard Brody interpret the video project as either setting forth a certain, self-evident claim, as in the case of the former, or as rendering impossible any meaning at all, as in the case of the latter, ${ }^{28}$ Morgan yields to the presence of uncertainty. This uncertainy characterizes ethical critique, the philosophical task of uncovering the Saying from the Said that Levinas has deemed necessary.

At the same time, for a film to undertake such a philosophical task means that the proximity of the Saying beyond representation inevitably becomes reduced to the materiality of the film's sounds and visuals. While the Saying disrupts the immanence of the Said, the Said immobilizes the approach of the Saying. ${ }^{29}$ Sounds and images signify and designate in the realm of the Said, thereby capturing, fixing, and confining the invisible Saying within the visible and within a narrative context. Although the Saying by definition eludes definition and representation, any attempt to respond to the approach of the Saying, or any discourse about the Saying, must have recourse to the rhetoric of representation. 
Hence, to conceive of a face means to conceive of an image, rather than the visage. While Levinas uses the term "face" for the "idea of Infinity" anterior to signification, this "face" inevitably falls into the realm of conceptualizing the human face as representative of the sight of Infinity. For Sam Girgus, close-up photographic images of actors function as icons of "ethical transcendence," which allow cinema to represent the unrepresentable. ${ }^{30}$ However, the application of the notion of the "face" to close-up shots of the faces of actors and actresses is precisely what Levinas means by freezing a face. Such figuration unethically petrifies the alterity of the face of the Other into an image that is immobile and plastic. Given that all discourse on the Saying unavoidably betrays the visage of the Saying into a phenomenological face, philosophy engages in the work of uncovering "the otherwise than being from the said" and of reducing the betrayal of the Saying in the Said. ${ }^{31}$ For Godard, this philosophical undertaking involves redeeming "the 'life' of images" that was subjected to "the imminent 'death' of the text." 32 The project of Histoire(s) du cinéma seeks to reduce the betrayal of the "something else" that is neither the image's power of pure presence nor immanent representation.

To pose an ethical function of cinema does not negate the idolatrous tendancy of images that capture the alterity of the Other in visible form. It does, however, challenge an "all or nothing" belief in or dismissal of images vis-à-vis the "unrepresentable." This is the position that Georges DidiHuberman has defended concerning photographic images of Auschwitz, and that is useful here. The photographs, Didi-Huberman explains, are neither everything nor nothing; they are "inadequate but necessary, inexact but true." 33 To dismiss an ethical function of images on the basis that images can only be ontological whereas the Saying is unrepresentable would risk subscribing to the "thesis of the unimaginable" that Didi-Huberman criticizes.

To illustrate his position, Didi-Huberman discusses the opposite methodologies of Claude Lanzmann's Shoah and Godard's Histoire(s) $d u$ cinéma. Didi-Huberman sees Lanzmann's project as affirmative of the "all or nothing" thesis: the only thing that can be shown is the absence of image, and this is the only way to teach everything about the Shoah. ${ }^{34}$ Contrary to this approach, Godard's video project shows nothing but images. This does not mean, however, as Didi-Huberman states in disagreement with Rancière, that the images are given a redemptive or resurrecting function. To interpret Godard's montage as such would ask too much of images, a move that is no less dangerous than the opposite extreme of nullifying them. ${ }^{35}$

\section{The Face-à-Face in Cinema}


Out of the vast corpus of materials cited in Histoire(s) du cinéma, the viewer is struck by the reappearance of one image throughout the entirety of the episode Une histoire seule. Most often superimposed with the red inscription l'ange or accompanied by vocal or visual references to histoire, the shot taken from Bergman's Fängelse of Thomas and Birgitta on either side of a cinematograph becomes familiarly symbolic of the episode's meditation on cinema's relationship with the forms of art it inherited. While the couple is looking out towards the projection of a silent-film reel, we know that the angel is looking back towards history. In Fängelse, a film that stages a "Hell on Earth" scenario, cinema is present in the few happy moments of life when the miserable protagonists experience an escape from death. Birgitta's single moment of joy and laughter in the movie occurs when Thomas shows her the silent film clip, but ironically this clip is about none other than a person trapped in a bedroom, being haunted by the devil and death. Birgitta's final escape from hell on earth occurs with death. A ray of light shines through the window of the dungeon-like room where she lies dead, which strongly resembles a projector light. Godard seems to affirm with the recurrence of Bergman's image that cinema's duty to flash a light back into the abyss of other histories is linked to its death, to the cinema that never took place.

The single history of cinema, une histoire seule, is made to look back at the general history in which cinema partakes in pre-original proximity with others. The repeated image of the projector instills a familiarity to the viewers' eyes that is rare amidst the extensive and rapid procession of materials. This familiarity, however, as soon as it begins to settle, is displaced by the image's relationship to and against the surrounding materials. The history behind the cinematograph includes a complex of interruptions between excerpts of other films, photographs, parts of paintings, superimposed book titles, voice-over utterances of book titles, the sound of the typewriter, music, and one could go on to list the manifold "others." Where the image of the couple behind the projector appears in the immense book of histories cinema inherited, in the "album de famille" from Proust to Manet as the voice-over describes, an unexpected close-up of a Giotto painting interjects, followed by a fragmented close-up of a text of Madame de Lafayette that transitions into a text of Faulkner, emerging and disappearing to the sound of flipping pages.

The estrangement that breaches the settlement of familiarity is due not only to the unpredictability of what cuts in before and after the recognizable image, not only to the citations that remain mysterious to the viewer unable to name the painting of which only a detail is shown or the book from which only a cut-off fragment is shown, but it is also due to the confrontation of multiple Balázsian-like physiognomies. The montage of Histoire(s) du cinéma certainly employs the sensibility and immediacy of vision provoked by the close-up faces of images. But one must go further and perhaps appeal to the 
Levinasian concept of the visage in order to better grasp not only the emergence but the ethical interaction between one physiognomy in proximity to and in communication with another radically different.

Levinas's philosophy of ethics is grounded on the notion of the face-toface relation as the only relation to the presence of the Other. ${ }^{36}$ Here the notion of the "face" must be clarified: the visage is transcendent and irreducible to my vision, comprehension, and definition, for it is "the idea of Infinity," "exceeding the idea of the other in me." 37 The face of the Other does not refer to a physical human face, but rather to the approach of alterity that cannot be conceptualized nor visualized. The sensibility of the face in its approach "de-sensibilizes itself": "The sensible presence of this chaste bit of skin with brow, nose, eyes, and mouth, is neither a sign allowing us to approach a signified, nor a mask hiding it. The sensible presence, here, desensibilizes itself in order to let the one who refers only to himself, the identical, break through directly." 38 The Saying of the face breaks through without being subsumed into the Said. One can extend Levinas's terminology and posit the mask as that through which the Saying breaks through or sounds through, the persōna.

The language of Histoire(s) du cinéma, then, as an uncovering of the Saying in proximity to the Other, must sound through without joining the immanent visibility of the Said on the screen. The encounter with the Other, as Levinas specifies, "does not consist in figuring as a theme under my gaze, in spreading itself forth as a set of qualities forming an image. The face of the Other at each moment destroys and overflows the plastic image it leaves me." 39 An evident tension arises between the transcendent alterity of the face of images and the representational quality that we as the viewers behold on the screen. To view the film as an ethical event means to open up a space for something other than what Rancière sees as a "co-belonging of forms and experience" comprised of "icons of pure presence." 40 For Rancière, the images in Histoire(s) du cinéma belong to an "originary sensorium" detached from the representative mode, and for this reason, as "icons of pure presence," these images can be assembled in an infinite number of associations. ${ }^{41}$ What this interpretation disregards, however, is the ethical element of the event in which images present themselves in the originary sensorium. The sensible presence emerges only to de-sensibilize itself so that the face of one image, non-coincidental to another, breaks or sounds through directly without being re-connected into meaningful relationships. It must be articulated how this breaking through of the visage happens without its betrayal into a symbolic montage.

For Jacques Aumont and Béla Balázs, alterity lies in the imminence of the face on the screen. Although Aumont and Balázs give privilege to the physical feature of the human face as distinct from Levinas's use of the term visage, their articulation of the otherness of the face visualized on the screen nears the problem of the cinematic visage in Levinas. While Balázs endows 
the technique of the close-up with an amplified quality of the Stimmung radiating from a physiognomy that is made total, exclusive, and idealized, Aumont distinguishes that the effect of the close-up is always present in the physiognomy of the face, even at a distance. ${ }^{42}$ In either case, the aesthetic idealization of the face, in what Aumont calls an expressive mode of representation, takes on a revelatory function that reduces cinematic expression to the operation of a totalized entity that closes upon itself and that runs counter to the alterity of the Levinasian visage. But Aumont is careful to specify that the physiognomy of the face - not just the human face but any object that radiates "charm" - plunges the viewer into a communion with a "visage-paysage, visage-monde," a communion that is at once intimate and infinitely strange. ${ }^{43}$ The imminence of vision in cinema, therefore, paradoxically also exposes the strangeness of otherness.

Levinas's own characterization of cinematic close-ups suggests this. In the notes he took while a prisoner of war, published as Carnets de captivité, and in Existence and Existents, the book that developed out of these notes, Levinas's interest in cinema is evident. A similarly contentious relationship can be traced with cinema as he had with literature. The meditations on cinema that evoke words such as "charm" and "strangeness" communicate an ambiguity that complicates any conclusion that would easily exclude an ethical possibility of cinematic expression from Levinas's philosophy.

In Existence and Existents, Levinas describes cinematic close-ups in this way: "[T]hey stop the action in which a particular is bound up with a whole, and let it exist apart. They let it manifest its particular and absurd nature which the camera discovers in a normally unexpected perspective-in a shoulder line to which the close-up gives the hallucinatory dimensions, laying bare what the visible universe and the play of its normal proportions tone down and conceal." 44 The word "hallucinatory" echoes the kind of vocabulary Levinas uses in "Reality and Its Shadow" to condemn the illusive and revelatory function of art. However, we read that what appears on the screen as a close-up arrests, interrupts what is bound up with a whole. Rather than to represent in a synthesized manner the reality of what cannot be thus arranged, this cinematic technique presents the strangeness of the particular in an unexpected exposition.

The philosopher's meditations on the concept of the Aufmachung in his Carnets de captivité are especially illuminating. In his second Carnet, Levinas evokes Alain Fournier's novel Le Grand Meaulnes and speaks of it, long before the cinematographic adaptation of the novel, in terms of scenes in a film: "La description des paysages non pas dans la connaissance qu' on peut avoir d'eux, mais dans leur Aufmachung. Premières scènes du film." 45 The connection between the process of Aufmachung (the "presentation," the "appearance," or the "packaging," hence the visual appearance and exteriority or materiality of things) and cinema is made clearer a few pages later in the notebook. Levinas writes, "Dans l'Aufmachung les choses 
apparaissent dans le mystère de l'étrangeté. Étrange - étranger. Dans leur étrangeté les choses se révèlent comme un mystère. C'est le charme du cinéma. Les paysages viennent machen sich auf vor uns. Souvenir essentiellement Aufmachung. Passé. Histoire, sujets historiques." 46 This effect of charm is what Balázs attributes to the close-up that is saturated by and resonates with a unique, strange aura, the Stimmung. The charm of cinema lies in its presentation, in which the face of things emerge in their strangeness and come to the foreground. Levinas's use of the word "charm" here is ambiguous: does he adhere to a kind of charm that is like the Saying, the otherness or strangness, that resonates in the reduction of the knowledge that one can have in the Said, or does he disapprove of this mysterious charm?

This uncertainty invites critical speculation. The above passages suggest that Levinas ascribes to cinema a presentation that belongs not to the regime of knowledge, but rather to the unknowable, the unrelatable, the unexpected, strange, and mysterious. The cinematic close-up interrupts the point of view of the Same and exposes, lays bare, the exteriority that confounds an internally thematized and unified conception. While this opens up the possibility of an ethical function of cinema, the problem lies in how the face of images puts forth speech without rendering itself visible as a representation of the Said. The charm of cinema that makes things appear in their mystery designates the manifestation of the visage in terms of vision. The face of things provokes a vision that appeals to the affective and the intuitive and not to interpretation, which for Aumont makes the mediation of speech irrelevant to the alterity of the face. The unmediated immediacy of the mute face that fills the entirety of the screen constitutes a vision confronted with alterity. On the contrary, the Levinasian visage comes forth as speech. It is the transcendent voice that strikes my totalizing gaze. The face speaks, rather than provoking vision. The Saying sounds through the packaging or mask of things, the Aufmachung. Here a distinction must be made between the mask, which I develop as the Aufmachung based on Levinas's use of the term, and the face. Levinas speaks of the mask as a material, "plastic form," which covers up the proximity of the face. The face, on the contrary, has no form; its presence is formal bareness, or nude of form ["dénudé des formes"]. ${ }^{47}$ Once the face is visualized, according to Levinas, one no longer encounters the face but rather a decipherable object.

The notion of cinema as Aufmachung returns in the third and seventh Carnets. In the third Carnet, the statement is explicit that cinema, "c'est l'art de l'Aufmachung et du point du vue." 48 The remark in the seventh Carnet is notable in that Levinas seems to not only compare his literary methods to those of film, but also specifies that the effects he seeks to obtain through his writing can be obtained by the work of Aufmachung, which he has previously marked as a function of cinema. In the comparison of his writing processes to film, Levinas writes: "Procédés du film - montage de mots pour 
éviter ces lourdes descriptions pour lesquelles ma main ne se lève pas." ${ }^{49}$ In this sense, the processes of film can be likened to Levinas's "montage de mots" that forms the very structure of his Carnets, fragments of notes. It is the technique of montage and not only the close-up charm of cinema, that distinguishes the cinematic visage from merely provoking vision. As noted above, Levinas's meditations reveal that far from linking elusive and shadowy images into what purports to be reality in the form of aesthetic transcendence, cinema rather functions as a divorce from illusions of continuity. The montage of images, like a montage of words contrary to the writing of weighty and lengthy descriptions, dismantles the classical order within the realm of the Same. As fragments of a landscape come and go in front of the viewer, the clashing of these fragments opens up the possibility of ctitical speech and the face of things break through. The image of the couple from Bergman's Fängelse is called into question, each time it reappears in Une histoire seule, by the imminence of the face of the preceding and following shot, which is put into question by the face of the following shot, and of the next shot, and of the next. Images are not only detached from their narrative context and from their normal perspective, but also from a foreseeable horizon, confounding the assimilation of the knowable into a familiar system. In this way, in cinema's practice of critique through montage, through its exposedness to questioning, alterity manifests as speech rather than vision.

Two things therefore characterize the exposition of the "idea of Infinity" in the "charm" of Histoire(s) du cinéma: the Aufmachung and fragmentation. Compared to Levinas's disapproval of the other "charms" of art, the charm of cinema is precisely what differentiates this type of art from the philosopher's denunciation of aesthetic captivation. The Aufmachung in Godard's montage materializes as a mask-like layer in the composition of superimposed images. References to the notion of the mask in Levinas's writings most often communicate a dissimulating function that violates the bare exposition of the face. Not until his meditations on cinematic techniques can we posit a productive and critical possibility for the function of the mask in between the Saying and the Said.

\section{The Mask and the Typewriter}

"Souvenir essentiellement Aufmachung. Passé. Histoire, sujets historiques." History as essentially Aufmachung. The problematic relationship to the abyss of the past is the principal concern behind Godard's montage as a process of Aufmachung. Five minutes into the first chapter of Histoire(s) du cinéma, his voice addresses the meaning of this title: "Histoires du cinéma avec un $s$ / Histoires du cinéma avec un $s$ / Toutes les histoires qu'il y aurait / qu'il y aura / ou qu'il y aurait / qu'il y a eu / qu'il y a eu." Godard composes histoires with an $s$, histoires narrated within the general, singular Histoire that 
belongs to all. A few minutes later in the same chapter, the narrator makes reference to the title once again, but this time in posing a problematic question: "est-ce que le $u$ qu'il y a dans produire empêche qu'il y ait dire dans produire?" The $e u$, or the $u$, in qu'il y a eu, marks the histoires that have passed. What has already passed into the abyss, that is, what never actually took place, lies at the center of produire. This $u$, the event that has been closed up yet pre-originally concerns cinematic production - particularly that of Hollywood, according to Godard -, obstructs the dire in produire, obstructs the Saying in producing. The problem having been thus posed in the introductory segment, the rest of Histoire(s) du cinéma unfolds as an endeavor to revisit the abyss that has passed by uncovering the dire precisely in the language of cinematic production.

Following the introductory remark on the title is an homage to Irving Thalberg - "Irving Thalberg a été le seul qui chaque jour pensait 52 films," repeats the voice-over -, after which follows a brief but saturated meditation on the intertextuality of remakes and adaptations of Hollywood and French classics. This "matter and memory" include cinematic remakes of other films, film adaptations of novels, television movie adaptations of novels, and film adaptations of historical accounts. Following a flashing iris shot of a camera and an operator on a crane superimposed with the text "la marque," is a scene showing Bela Legosi from La marque du vampire, a talking re-make by Tod Browning of the silent film London after Midnight. The illusion to the filmic adaptation of Jean Cocteau's novel is made by the narrator who utters "Les enfants terribles." The same flashing iris shot of the camera on a crane is then superimposed with the text "du vampire," followed by the narrator's voice that says "et il a fallu que cette histoire passe par là." Which way? Par là : the camera crane that failed to see history, the power of Hollywood (emblematized by Thalberg), and French cinema and its classic works of literature (self-emblematized by Godard flipping through his books and pronouncing the title of Balzac's novel, Le Lys dans la vallée). History went this way and produced this story, cette histoire, comprised of each story told by the camera, the text, the talking, and the silent. This work here and its montage must uncover the "something else," the dire from the produire.

Cinematic montage as an ethical event uncovers the Saying from the already Said by presenting fragments that appear in front of us in the Aufmachung. Like Duras's film that filmed its failure of ever taking place, the fragments create not a general history, but present themselves in front of us as cinema flashes a light into the abyss of the eu. In the Aufmachung, that is, they present themselves in front of us in the materiality through which the Saying of images breaks through. In between the overlapping layers of images, one can see the thin, translucent mask-like layers separating one image superimposed on another. The materiality of the Aufmachung sets up the difference between the Saying and the Said. As a layer in between the cinematic and literary histories, in between this story of the camera 
approaching this Other that is the text, the mask functions to reduce the effect of the Said for the visage of one image to sound through the mask. In terms of cinema and literature, the Saying of literature interrupts the particular history told in the Said of cinema, and inversely, the Saying of cinema interrupts the history told in the Said of literature.

Following La marque du vampire and Les enfants terribles, the sound of the electric typewriter emerges to prominence on a black screen, until the shot of the camera crane returns in rapid alternation with the superimposed image of Godard in his library and the iris of Thalberg's photograph. The staccato of fragmentary montage of words cuts the images into fragments that flash in front of us. The narrator once again utters, "et il a fallu que cette histoire passe par là," while the staccato beat flashes fragments that uncover the speech of something else than what history produced.

A montage of words as much as a montage of images. The heavy staccato of the typewriter overwhelms the sound of classic titles pronounced through Godard's rather somber utterance of "Les fleurs du mal" and the voice-over's stating, "tel que l'a décrit Scott Fitzgerald." What Scott Fitzgerald described - the life of a film producer's rise in Hollywood, namely that of Thalberg, told in the unfinished novel published as The Last Tycoon - will inspire Kazan's last film, Le Dernier Nabab, as well as be adapted on television. The screen then reveals a scene from Cecil B. DeMille's 1956 partial remake of the 1923 silent version of Les Dix commandements, while the auditory presence of the typewriter persists. The voice-over repeats, "Les fleurs du mal," overlapping with the statement "pour que ça se mette à exister / ça." This followed by the utterance "La Peste," Camus's novel adapted into a 1992 film by Luis Puenzo, and the sequence's last reference is made by a musical excerpt from Liszt's Faust-Symphonie, a portrait based on Goethe's Faust, also adapted into films. At the declaration of "ça," glimpses of Les Dix commandements, murmurs of Scott Fitzgerald, Les fleurs du mal, and La Peste, and insinuations of The Last Tycoon, Le Dernier Nabab, and Faust, all assemble as a montage of words, images, and music. In order that this might exist at the proximity of one fragmented histoire to another. As Godard's voice continually reminds us, however, the this that might come to exist out of what has never taken place emerges from having its part in history's already Said: "la puissance de Hollywood." The typewriter continually responds, therefore, to the demand of the Saying to write and re-write what is lost in the immanence of "ça," the immanence of what is seen and Said.

The superimposition of scenes of films with texts that recall titles of books, with the sound of a typewriter, with voice-overs, and with music, reveal the histoires that are disparately represented in the Said, yet always already in proximity. These elements carry a paratextual function as one art approaches another and another approaches yet another, creating and restructuring what Rancière calls "event-worlds" that program the reading 
of each art event. The approach and proximity of one art to another accomplishes the uncovering of the History that has passed, giving possibility for the gulf of the $u$ in produire to be made to speak in a language of the dire.

To understand intertextuality in Histoire(s) du cinéma as a symbolic coexistence of an infinite number of "event-worlds" in history, however, would be reductive. Ringing loudly in contemporaneity with images of the already Said of history, the abruptly disconnected rhythm of the typewriter inhibits the stories both from merging into consensus or dispersing into schizophrenic chaos. ${ }^{50}$ Something else happens that is more complex in the composition of images, than the symbolic montage that Rancière sees in Histoire(s) du cinéma's redemptive story. In the work of Aufmachung as a cinematic function, the faces of images present themselves before us superimposed; the translucent mask hinders mergence and the broken intervals of typewriting inhibits synchrony. The visible mask as the layer of the Aufmachung and the audible fragmenting of the typewriting express a dia-chrony, a non-coincidence of event-worlds. The "ethical interruption of essence" consists in "retaining an echo of the reduced said in the form of ambiguity, of diachronic expression." 51 The echo of the Saying and the fixed image of the Said are not synchronic, but rather in two times, dia-chronic, the difference of which is expressed in the layering and in the interval.

The final image of the sequence under discussion perhaps speaks most forthrightly. While the narrator declares "La puissance de Hollywood" and the musical excerpt from Faust-Symphonie is heard in the background, an image of Godard in his library rapidly alternates with an image of a piled mass of corpses. The speed of the alternation increases with the heightened sound of the music. In terms of the two images that compose this shot, the Said of one image is interrupted and is called into relation to the Saying of another image. The alternation of the color image of the cinematographer in his library and the black and white image of a mass of corpses becomes so rapid to the point of blurring the disturbingly contrasting images together. This would be one instance among the countless in which the "eventworlds," in Rancière's reading, "coexist with the infinity of other eventworlds that belong not only to all other films but also to all other forms of illustration of the century; they become susceptible to striking an infinite number of relationships amongst themselves as well as with all the events of the century." 52 Two forms of illustration are juxtaposed and pose the possibility of a communal history. To reduce the dia-chrony, however, into a communal and symbolic operation of all-things-merge-together, would be to disregard the ethics of the process in the interval. If "coupled and reassembled with any of the other images that belong to this great continuum of forms," as Rancière writes, the faces of images would take form rather than break through with a charm. ${ }^{53}$ The shot of Godard and the shot of the corpses, although responding to and in proximity of each other, 
do not merge; rather, the two shots are separated by the fragmenting and masking art of the Aufmachung.

\section{A Saying Otherwise Said}

“[R]approcher les choses / qui n'ont encore jamais été rapprochées / et ne semblaient pas / disposées à l'être," reads the text, three times as it appears, towards the end of the last chapter of Histoire(s) du cinéma. As is expressed in Fatale beauté, the second chapter of Histoire(s) du cinema, the unbridgeable, diachronic gap, or le trou, alluding to the title of Jacques Becker's film, becomes surrounded by "le temps "rê...vé," and finally finds "le temps retrouvé." Cinematic language furnishes the Saying with a language of its own, which gives not only a possibility but also the necessity of a history that speaks. History as a dia-chronic time is re-written as the Saying fragments the Said, affirming "the impossibility of the statement while venturing to realize this impossibility by the very statement of this impossibility." 54 Such is the task of ethics that cinema realizes through its language "otherwise said."

According to Levinas, the only redemptive possibility for art to be rescued from the irresponsible idolatry of fixed resemblances of reality is found in ethical critique, which can be equated to the philosophical task of drawing out the Saying from the Said. ${ }^{55}$ The following is Levinas's understanding of the role of critique, contrary to the ontology of aesthetics:

Not content with being absorbed in aesthetic enjoyment, the public feels an irresistible need to speak. The fact that there might be something for the public to say, when the artist refuses to say about artwork anything in addition to the work itself, the fact that one cannot contemplate in silence, justifies the critic. He can be defined as the one that still has something to say when everything has been said, that can say about the work something else than the work. ${ }^{56}$

The work that has been said belongs to the realm of totality, where art can only continue a resounding of the narrative of the Said. The critic, however, seeks the "something else." "[T]he immobile statue has to be put in movement and made to speak." 57

After everything has been said and told in stories, Godard revisits, rewrites, flashes the light back onto the images and makes something still speak. This Saying is accomplished in the ethical language of Aufmachung pronounced through the mask. This language challenges the possibility of the configuration of spaces that draw an equivalence, within the sensible, between one element and another that is radically outside the sensible presence, that is, de-sensibilized. In this way it poses a different kind of possibility, an ethical possibility. The ethical element of Godard's cinematic critique lies in the possibility of the Saying of one image and the Saying of 
another image to approach each other, to interrogate each other in the form of the Said, while maintaining the tension of this possibility of speech that sounds through the mask in between the Saying and the Said.

We come back here to Duras's expression of her anguish in realizing a film after the event of writing: "Cette histoire ici, qui est à tous, j'avais le droit, moi, d'en avoir ma part puisque c'est comme ça que moi, je la partage avec les autres, en écrivant. Mais peut-être n'avais-je pas le droit ici [...] une fois l'écriture passée, une fois pénétrée et refermée cette nuit commune du gouffre, de faire comme s'il était possible d'y revenir voir une deuxième fois." ${ }^{58}$ In writing, she states, the author shares the story, shares history, with others - histoire(s) with an s. It is an histoire(s) that has been approached by books, films, filmic remakes of books, all other art forms. Ethical critique responds that yes, it is not only possible but a necessary duty to go back and interrupt the abyss a second time.

${ }^{1}$ Marguerite Duras, Le Navire Night (Paris: Mercure de France, 1979), 14.

2 I owe to Celine Scemama's "La « partition » des Histoire(s) du cinéma de Jean-Luc Godard” for the sources referenced in the film, available online: http://cri-image.univparis1.fr/celine/celine.html

3 In the introduction to the special issue on Godard and philosophy of the Journal of French and Francophone Philosophy 18.2 (2010): 1-7, John Drabinski notes the abundance of moments in Godard's films in which philosophical books are referenced, suggesting the need for further study of the more complex relationships between Godard's works and philosophy.

${ }^{4}$ Although the capitalization of the terms "saying" and the "said" in Levinas's works varies, this paper will use the capitalized form for consistency, unless they appear otherwise in the original text.

${ }^{5}$ Emmanuel Levinas, Otherwise Than Being, or, Beyond Essence, trans. Alphonso Lingis (Dordrecht: Kluwer Academic Publishers, 1991), 5.

${ }^{6}$ Ibid., 23. In Otherwise Than Being, or, Beyond Essence, Levinas resorts to using a multitude of terms to characterize the Saying, which precisely escapes characterization or definition. Such terms include "proximity of one to the other," "approach," "one for the other," "breakup of essence," "hostage," “sacrifice," "responsibility for another," "breaking up of inwardnesss," "exposedness to the other," and "substitution."

7 lbid., 156.

8 Ibid., 40, 182.

9 For an illuminating insight into the topic of Levinas's elliptical references to authors, see Eric Marty, “Emmanuel Levinas avec Shakespeare, Proust et Rimbaud" in Le souci de l'art chez Emmanuel Levinas, ed. Danielle Cohen-Levinas (Paris : Manucius, 2010) 85-103.

${ }^{10}$ Emmanuel Levinas, Time and the Other: And Additional Essays, trans. Richard Cohen (Pittsburgh: Duquesne University Press, 1987), 72. 
11 Robert Eaglestone, Ethical Criticism: Reading after Levinas (Edinburgh: Edinburgh University Press, 1997), 121.

12 Along with Robert Eaglestone's work cited here, Jill Robbins's Altered Reading: Levinas and Literature (Chicago: University of Chicago Press, 1999) and Steven Shankman's Other Others : Levinas, Literature, Transcultural Studies (Albany : SUNY Press, 2010) are other principal works on literary criticism and literature as an ethical practice.

13 Jill Robbins, Altered Reading: Levinas and Literature (Chicago: University of Chicago Press, 1999).

14 Emmanuel Levinas, Totality and Infinity: An Essay on Exteriority, trans. Alphonso Lingis (Pittsburgh: Duquesne University Press, 1969), 92.

15 lbid., 91.

16 Emmanuel Levinas, "Reality and Its Shadow," in The Levinas Reader, trans. Alphonso Lingis (Malden, MA: Blackwell Publishers, 1989), 130.

17 Levinas, Otherwise Than Being, 7.

18 For example, see Sam Girgus's Levinas and the Cinema of Redemption: Time, Ethics, and the Feminine (New York: Columbia University Press, 2010).

19 John E. Drabinski, Godard between Identity and Difference (New York: Continuum, 2008). For other examples, see Joseph Mai, Jean-Pierre and Luc Dardenne (Urbana: University of Illinois Press, 2010) and the various articles in the special issue of Film Philosophy edited by Sarah Cooper, 11.2 (2007).

20 Ibid., 132.

21 Jacques Rancière, Film Fables, trans. Emiliano Battista (New York: Berg Publishers, 2006); Jacques Rancière, "The Saint and the Heiress: A Propos of Godard's Histoire(s) du Cinéma," trans. T. S. Murphy, Discourse 24, no. 1 (2002): 113-119.

22 Rancière, "The Saint and the Heiress: A Propos of Godard's Histoire(s) du Cinéma," 116.

23 Jean-Luc Godard, "Third Voyage," in Introduction to a True History of Cinema and Television, trans. Timothy Barnard (Montreal: Caboose, 2012), 4.

24 Ibid.

25 Jean-Luc Godard, “First Voyage," in Introduction to a True History of Cinema and Television, trans. Timothy Barnard (Montreal: Caboose, 2012), 5.

26 Ibid., 4.

27 In this montage of scenes from Hitchcock's films, the voice-over speaks on behalf of the viewers that we remember the images but have forgotten the narratives underlying them. For a close reading and discussion of how Godard escapes Rancière's judgment of pure aesthetic formalism, see Daniel Morgan, Late Godard and the Possibilities of Cinema (Berkeley: University of California Press, 2012), 172-177.

28 Richard Brody, Everything Is Cinema: The Working Life of Jean-Luc Godard (New York: Metropolitan Books, 2008).

${ }^{29}$ Levinas, Otherwise Than Being, 5. 
30 Sam B. Girgus, Levinas and the Cinema of Redemption: Time, Ethics, and the Feminine (New York: Columbia University Press, 2010), 84.

31 Levinas, Otherwise Than Being, 7, 156.

32 Rancière, Film Fables, 171.

33 Georges Didi-Huberman, Images in spite of All: Four Photographs from Auschwitz, trans. Shane Lillis (Chicago: University of Chicago Press, 2008), 39.

34 Ibid., 128.

35 Ibid., 120-150.

${ }^{36}$ Levinas, Totality and Infinity, 39.

37 Ibid., 50.

38 Emmanuel Levinas, Entre Nous: Thinking-of-the-Other, trans. Michael Smith and Barbara Harshav (London: Continuum, 2006), 29.

${ }^{39}$ Levinas, Totality and Infinity, 50-51.

40 Rancière, Film Fables, 177.

41 Ibid., 175.

42 Jacques Aumont, Du Visage au Cinéma (Paris: Editions de L’Etoile, 1992), 85.

43 lbid., 98.

${ }^{44}$ Emmanuel Levinas, Existence and Existents, trans. Alphonso Lingis (The Hague: Martinus Nijhoff Publishers, 1978), 49.

45 Emmanuel Levinas, CEuvres: Carnets de Captivité et Autres Inédits, vol. 1 (Paris: Grasset, 2009), 81.

46 lbid., 1:82.

${ }^{47}$ Levinas, Entre Nous, 130.

${ }^{48}$ Levinas, Carnets, 1:102.

49 Ibid., 1:195.

50 Jacques Rancière, "Sentence, Image, History," in The Future of the Image (New York: Verso, 2007), 33-67.

51 Levinas, Otherwise Than Being, 44.

52 Rancière, Film Fables, 175.

53 Ibid., 178.

54 Levinas, Otherwise Than Being, 7.

55 Ibid., 7.

${ }^{56}$ Levinas, “Reality,” 130.

57 Ibid., 142. 
60 The Ethics of Uncovering the Something Else

${ }^{58}$ Duras, Le Navire Night, 10. 